\title{
Sütten Kesimin Keçilerin Süt Verimi ve Süt Kompozisyonu ile Oğlakların Büyüme Hızına Etkisi
}

\author{
Cemil Tölü* Kamilcan Hardal Türker Savaş \\ Çanakkale Onsekiz Mart Üniversitesi Ziraat Fakültesi Zootekni Bölümü, Terzioğlu Yerleşkesi, 17100 Çanakkale \\ "Sorumlu yazar: cemiltolu@comu.edu.tr
}

Geliş Tarihi: 08.10.2019

Kabul Tarihi: 30.10 .2019

\section{Öz}

Bu çalışmada, sütten kesim döneminin süt keçilerinde süt miktarı, süt bileşenleri ve oğlakların büyüme hızına etkileri belirlenmiştir. Araştırma Türk Saanen genotipi 8 baş keçi ve tekiz oğlakları üzerinde yürütülmüştür. Çalışmada süt kontrolleri sütten kesim öncesi dönemde elle ve emiştirme yoluyla yapılırken, sütten kesim sonrası elle sağım yöntemi kullanılarak gerçekleştirilmiştir. Süt ölçümleri 22 gün boyunca 07:0008:00 ve 17:00-18:00 saatleri arasında yapılmıştır. Oğlaklar 60. günde sütten kesilirken, sütten kesim öncesi ve sonrası 11'er gün toplam 22 günlük süreçte canlı ağırlık takipleri yapılmıştır. Çalışmada, oğlakların canlı ağırlıklarının sütten kesim dönemleri ve cinsiyetlere göre önemli ölçüde farklılık gösterdiği belirlenmiştir $(\mathrm{P} \leq 0,05)$. Erkek oğlaklarda canlı ağırlık değişiminde herhangi bir olumsuzluk görülmezken, dişi oğlakların sütten kesimden sonra canlı ağırlıklarının düştüğü ve 6 . günde dengelendiği görülmüştür. Sütten kesim öncesi ve sütten kesim sonrası dönemlere göre süt miktarı, yağsız kuru madde oranı, protein oranı ve laktoz oranının sütten kesimden sonra önemli ölçüde düştüğü belirlenmiştir $(\mathrm{P} \leq 0,05)$. Sabah sağımlarında süt miktarının akşam sağımlarından \%60 daha yüksek olduğu gözlenmiştir $(\mathrm{P} \leq 0,05)$. Sabah sağılan sütlerde süt bileşenleri düşük olmakla birlikte sadece süt yağ oranındaki fark önemli bulunmuştur $(\mathrm{P} \leq 0,05)$. Türk Saanen keçilerinde sütten kesim periyodunun etkilerinin özellikle dişi oğlaklar ve anneler açısından daha fazla sayıda hayvan ve laktasyonun daha fazla süreci ile ele alınmasına ihtiyaç olduğu düşünülmektedir.

Anahtar Kelimeler: Türk Saanen, süt miktarı, süt bileşenleri, canlı ağırlık, cinsiyet

\section{Effects of Weaning on Milk Yield and Milk Composition of Does and Growth Rate of Kids}

\section{Abstract}

In this study, effects of weaning period on milk yield, milk compositions of goats and growth rate of goat-kids were determined. The research was carried out on 8 head goats and singles born kids of Turkish Saanen genotype. In the study, milk controls were carried out by hand and suckling in the pre-weaning period, and after weaning using hand milking method. Milk measurements were performed for 22 days between 07:0008:00 and 17:00-18:00. While the goat-kids were weaned on day 60, live weights were monitored for a total of 22 days in 11 days before and after weaning. In the study, it was determined that the live weights of the goat-kids differed significantly according to weaning periods and genders $(\mathrm{P} \leq 0.05)$. While there was no negativity in live weight changes in male goat-kids, it was observed that female goat-kids weights decreased after weaning and stabilized on the $6^{\text {th }}$ day. It was determined that the milk yield, dry fat content, protein content and lactose ratio decreased significantly after weaning $(\mathrm{P} \leq 0.05)$. It was observed that milk yield in the morning milking was $60 \%$ higher than the milking in the evening $(\mathrm{P} \leq 0.05)$. Although milk components were low in the morning, only the difference in milk fat content was significant $(\mathrm{P} \leq 0.05)$. It is think that the effects of weaning period in Turkish Saanen goats need to be addressed with more processes of lactation and animals, especially for female goat-kids and dams.

Key words: Turkish Saanen, milk yield, milk content, live weight, gender

\section{Giriş}

Sütten kesim, memeli hayvanlarda yavruların süt ve süt ikame yemleri ile beslenmelerinin bırakılarak tamamen kaba/kesif yem ile beslenmeye başladığı ve aynı zamanda annesini emen yavruların annelerinden ayrıldıkları dönemdir. Sütten kesim beslenme ve duyusal stres bakımından yavrular için önemli bir eşik konumundadır (Uğur ve ark., 2004; Magistrelli ve ark., 2011; Tölü ve Savaş, 2012). Yavrular için anne, önemli bir besin kaynağı olduğu kadar önemli bir sosyal partner 
Oğlaklarda sütten kesimin zamanlamasında farklı kriterler dikkate alınmakla beraber, bunların içinde oğlağın yaş, canlı ağırlık ve cinsiyeti öncelikli unsurlardır. Oğlağın yaşı ve canlı ağırlığı yem tüketimi bakımından ipuçları verse de, bazı ırkların oğlaklarında belirlenen sütten kesim ağırlığına daha erken yaşlarda ulaşabilmektedirler. Ancak sütten kesime kadar hızlı gelişen oğlakların daha yavaş gelişenlere göre sütten kesimden daha çok etkilendiği bilinmektedir (Pala ve ark., 2005). Doğum ağırlıkları belli sınırlar içinde diğer hayvanlara göre daha yüksek olan küçükbaş hayvanlarda, hızlı günlük canlı ağırlık artışı ile hayvanların sütten kesim ağılıklarının da yüksek olması beklenmektedir (Wollny, 2000). Fakat sütten kesimde canlı ağırlık ve yaşın yanında, oğlağın kaba veya kesif yem tüketimi de dikkat alınmalıdır (Morand-Fehr, 1981). Oğlağın yeme alışması belli bir yaşa ulaşmasının yanında, oğlak büyütme programının da oğlağın kaba/kesif yem tüketimini teşvik edecek biçimde düzenlenmesi ile de ilişkilidir (Tölü ve Savaş, 2012). Oğlağın günlük ihtiyacından fazla süt üreten keçi genotiplerinde doğumdan 1 hafta sonrasında en az bir öğün sağımın başlaması bu anlamda önem arz etmektedir (Savaş, 2007).

Oğlaklar veya diğer çiftlik hayvanları ile ilgili sütten kesim sürecini değerlendiren çalışmalarda, sütten kesimin etkisinin hayvanlarda uzun süreçleri içine alan yaklaşımlar olduğu görülmektedir (Uğur ve ark., 2004; Pala ve ark., 2005; Tölü ve Savaş, 2012; Panzuti ve ark., 2018). Diğer yandan sütten kesimin etkilerini birkaç günlük kısa süreçlerle değerlendiren yaklaşımlar bulunmaktadır (Lefcourt ve Elsasser, 1995; Ungerfeld ve ark., 2011). Ayrıca sütten kesimin, analarda oluşturduğu etkilerden daha çok yavrularda ortaya çıkardığı etkiler üzerine yoğunlaşıldığı dikkati çekmektedir. Süt keçilerinde süt verimi ve kompozisyonuyla ilgili olarak sıcaklık stresi çevresel kökenli streslerin etkilerinin irdelendiği görülürken, sütten kesim sürecinin süt miktarı ve süt bileşenlerine etkileri üzerinde durulmamıştır (Hamzaoui ve ark., 2013; Contreras-Jodar ve ark., 2018).

Ülkemizde küçükbaş hayvan yetiştiriciliğinde genellikle analı (doğal) büyütme yöntemi uygulanmaktadır. Oğlaklarda sütten kesim zamanları ve yöntemleri ise bölge (pazar, mandıra süt alım zamanı, iklim, mera vb.), ırk, üretim sistemi ve büyütme programlarına göre değişebilmekle beraber 412 hafta arasındadır (Savaş, 2007). Bazı yetiştiriciler oğlakların sütten kesiminden sonra annelerinin süt verimlerinin düştügünü ifade etmektedirler. Bu çalışmada, sütten kesimin hemen öncesi ve sütten kesimin hemen sonrası ardışık günlerde oğlaklarda canlı ağırlık değerleri ile keçilerde süt miktarı ve bileşimindeki değişimler incelenmiştir.

\section{Materyal ve Yöntem}

$\mathrm{Bu}$ çalışma, Çanakkale Onsekiz Mart Üniversitesi Teknolojik Tarımsal Araştırma Merkezi (TETAM) Küçükbaş Hayvan Yetiştirme Birimi'nde yarı entansif koşullarda yetiştirilen 8 baş 4-5 yaşlı Türk Saanen keçisi ve 8 baş (3 Dişi; 3 Erkek) oğlakları ile yapılmıştır. Birim yaklaşık 250 da araziye sahip olup, bu alanın 80 da'1 tarla, 100 da'1 doğal mera niteliğindedir. Çalışma sütten kesim öncesi 11 gün, sütten kesim sonrası 11 gün olmak üzere 22 gün sürmüştür.

Oğlaklar 1 haftalık yaştan sonra ad libitum olarak yonca kuru otu ve oğlak büyütme yemi ile beslenmiş ve önlerinde sürekli taze su bulundurmaya özen gösterilmiştir. Keçiler ise hayvan başına 1 $\mathrm{kg} /$ gün kesif yem, $0,75 \mathrm{~kg} / \mathrm{gün}$ yonca kuru otu, $2 \mathrm{~kg} /$ gün misır silajı ile beslenmiştir. Ayrıca işletme yapısında bulunan meradan günde 6-8 saat otlayarak yararlanmışlardır. Çalışmada, oğlakların sütten kesim öncesi ve sonrasında 11 günlük süre ile canlı ağırlık tartımları 20 g'a duyarlı baskül ile yapılmıştır.

Süt ölçümleri sütten kesim öncesinde elle sağım ve emiştirme yöntemi (tart-emzir-tart) ile yapılırken, sütten kesim sonrasında düzenli olarak keçilerde elle sağım yöntemi ile süt verim ölçümleri yapılmıştır. Sütten kesim öncesinde oğlaklar önce aç, sonra tok olarak tartılmışlardır. Oğlaklar 30 dakika süre ile emzirilmiştir. Emişme sonrası memede kalan süt elle sağılarak $2 \mathrm{~g}$ hassasiyetindeki terazide miktarı belirlenmiştir. Oğlak canlı ağırlık farkı ve memede kalan süt toplanarak toplam süt miktarı elde edilmiştir (Tölü ve ark., 2010; Tölü ve Arıkan, 2019). Sağılan sütlerden alınan örneklerden süt bileşenlerinin analizlerini günlük olarak Çanakkale Onsekiz Mart Üniversitesi Ziraat Fakültesi Zootekni bölümüne ait laboratuvarda Milk-Lab süt analiz cihazı ile yapılmışıtır (Tölü ve ark., 2016).

Oğlak canlı ağırlıklarının tekrarlamalı ölçümler varyans analizinde dönem (sütten kesim öncesi, sütten kesim sonrası), cinsiyet (dişi, erkek) ve interaksiyonların yer aldığı model kullanılmıştır. 
Süt miktarı ve bileşenlerinin tekrarlamalı ölçümler varyans analizinde ise, modelde dönem (sütten kesim öncesi, sütten kesim sonrası), periyot (akşam, sabah) ve bu faktörlere ilişkin interaksiyon yer almıştır. Süt bileşenlerinin analizinde ayrıca bu faktörlerin yanında süt miktarı modele kovaryant olarak eklenmiştir. Çoklu karşılaştırmalarda TUKEY testi kullanılmıştır (SAS, 1999).

\section{Bulgular ve Tartışma}

Çalışmada, oğlakların canlı ağırlıklarının sütten kesim dönemi ve cinsiyete göre önemli ölçüde farklılık gösterdiği belirlenmiştir (Çizelge 1). Oğlaklarda sütten kesimden sonra canlı ağırlık artış1 devam etmiştir (Şekil 1). Erkek oğlaklar sütten kesimden canlı ağırlık bakımından olumsuz etkilenmezken, dişi oğlakların sütten kesimden sonraki ilk iki günde canlı ağırlıkları düşmüş, 3. günde ise ani yükselme sonrası 6 . ile 7. günlerde kararlı bir yükselme eğilimine girmişlerdir. Bu bulgu dişi oğlakların 3. günde yem tüketimlerini artırarak sütten kesim şokunun üstesinden gelmeye çalıştıklarına işaret etmektedir (Tölü ve Savaş, 2012). Sütten kesim döneminde oğlakların kaba/kesif yem tüketimine alışmış olmaları, sütten kesimin olumsuz etkilerini minimize etmede ve canlı ağırlık kayıplarını durdurmada etkili olduğu bilinmektedir (Magistrelli ve ark., 2011). Erkek oğlaklar ise sütten kesimden sonraki 4. günde nispeten az bir düşüş yaşarken, sonrasında önceki günlere ve dişilere göre canlı ağırlıklarını daha kararlı biçimde artırmaya devam etmişlerdir. Nitekim sütten kesim öncesinde dişi ve erkek oğlakların canlı ağırlıkları birbirine yakın iken, sütten kesim sonrasında erkek oğlakların canlı ağırlıkları dişi oğlaklardan önemli ölçüde daha yüksek olmuştur $(\mathrm{P} \leq 0,05)$. Uğur ve ark. (2004), aynı genotiple farklı sütten kesim yaşlarını karşılaştırdıkları çalışmalarında, doğum ve 4 aylık ile sütten kesim ve 4 aylık süreçte erkek oğlakların dişi oğlaklardan önemli ölçüde daha fazla canlı ağırlık artışı sağladıklarını belirlemişlerdir. Deeming ve ark. (2016) Yeni Zelanda'da on altı süt keçisi işletmesinde sütten kesime kadar ve sütten kesim sonrası 2 haftalık periyodu karşılaştırdıkları çalışmalarında, işletmelerin on birinde sütten kesim sonrası süreçte oğlakların sütten kesim ağırlıklarını kaybettiklerini belirlemişlerdir. Sütten kesim yaşı sütten kesim stresinde önemli bir etken olmakla birlikte, sütten kesim ağırlığı da oğlakların sütten kesim stresini ne derecede yaşayacağını önemli ölçüde etkilemektedir (Tölü ve Savaş, 2012).

Çizelge 1. Sütten kesim dönemleri ve oğlak cinsiyetlerine ait en küçük kareler ortalamaları \pm standart hataları ve P değerleri

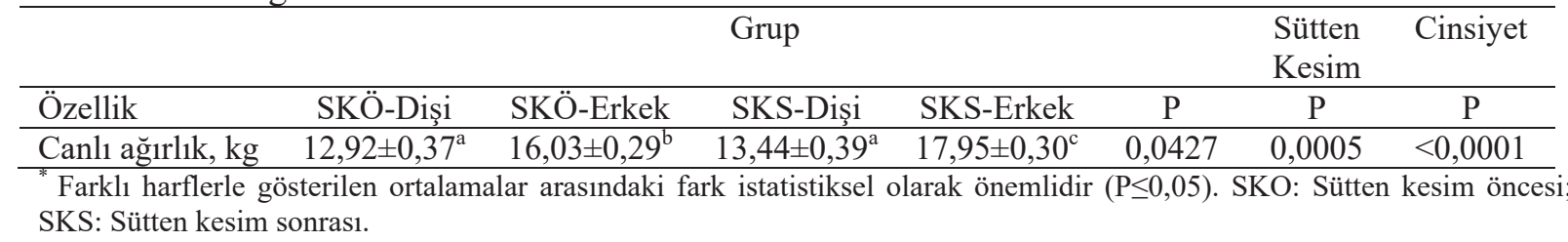

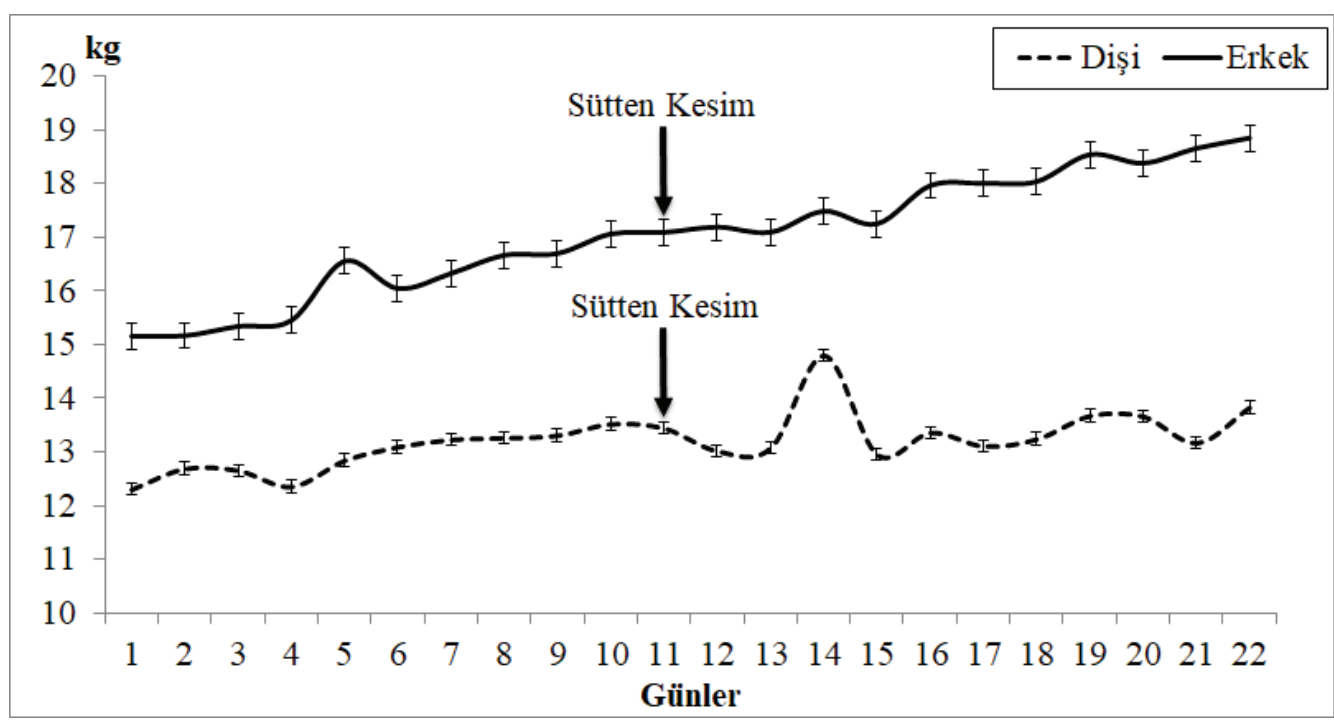

Şekil 1. Günlere göre oğlak cinsiyetlerine ait canlı ağırlık ortalamaları değişimi, kg (ortalamayı gösteren eğri üzerindeki çizgiler standart hatalara aittir). 
Çalışmada keçilerde günlük süt veriminin sütten kesim öncesi ve sütten kesim sonrasına göre önemli ölçüde farklılaştığı tespit edilmiştir (Çizelge 2). Sütten kesim sonrasında ortalama günlük süt verimi sütten kesim öncesine göre önemli ölçüde düşmüştür $(\mathrm{P}=0,0228)$. Emzirme döneminde gece boyunca sürekli emen oğlağın "uyarısı" ve memede süt birikiminin daha az olması bu farkın bir nedeni olabilir. Zira emişmenin diğer uyaranlara göre daha yüksek oksitosin hormon salınımına neden olabileceği ve süt üretimini de artırabileceği bilinmekle beraber (Tancin ve Bruckmaier, 2001), keçilerde bu uyaranın sı ğırlardan daha düşük seviyelerde olduğu belirtilmektedir (Marnet ve McKusick, 2001). Çalışmada Türk Saanen keçilerinin süt verimlerinin sütten kesimden sonraki ilk 4 günde süt verimlerinin düştüğü görülmektedir (Şekil 2). Şam keçilerinde yapılan çalışmada, emiştirilen anneler ile süt ikame yemi kullanılarak büyütülen oğlakların annelerinin 60 günlük ve laktasyon süt verimlerinin benzer seviyelerde olduğu belirlenmiştir (Keskin ve Biçer, 2002). MurciaGranada keçilerinde yapılan çalışmada, doğumdan 48 saat sonra oğlaklarından ayrılan ve 7 haftalık yaşta oğlaklarından ayrılan keçilerin 0-7 haftalık ve 8-30 haftalık dönemdeki süt verimleri benzer gerçekleşmiştir (Peris ve ark., 1997). Buna karşın Florida 1rkı keçilerde, emiştirilen ve yavrusu süt ikame yemi ile büyütülen keçilerin süt verimleri karşılaştırılmış ve emiştirilen keçilerin süt verimlerinin diğerlerine göre önemli ölçüde yüksek olduğu belirlenmiştir (Delgado-Pertinez ve ark., 2009). Ost-Friz koyunlarında doğumdan 24 saat sonra kuzudan ayrilan, günde 9 saat kuzusuyla birlikte olan ve sürekli kuzusuyla kalan koyunların ortalama günlük süt verimleri üç gruba göre de önemli ölçüde farklılık göstermiştir (Mckusick ve ark., 2001). Süt sığırlarında 7, 14 ve 21 gün emiştirilen ve sütten kesilen buzağıların annelerinin 305 günlük laktasyon süt verimlerinde 7 ve 21 günlük emiştirilenler arasında, 2. aydaki süt verim ortalamalarında ise 21 günlük emiştirilen annelerin süt verimlerinin diğer gruplardaki annelerden önemli ölçüde daha düşük süt verimine sahip olduğu görülmüştür (Kisac ve ark., 2011). Çalışmada, sabah sağımında akşam sağımına göre daha yüksek süt verimi belirlenmiştir $(\mathrm{P} \leq 0,05)$. Daha önce keçilerde yapılan çalışmalarda özellikle akşama göre daha uzun süre bulunan sabah sağımında keçilerden akşam sağımına göre daha yüksek süt elde edildiği bilinmektedir (Pala ve Savaş 2006; Tölü ve ark., 2016).

Çizelge 2. Sütten kesim dönemleri ve sağım periyotlarına göre günlük süt verimi $(\mathrm{kg})$ ve süt bileşenlerine (\%) ait en küçük kareler ortalamaları \pm standart hataları ve P değerleri

\begin{tabular}{lccc|ccc|c}
\hline & \multicolumn{2}{c|}{ Sütten Kesim Dönemi (SKD) } & \multicolumn{3}{|c|}{ Sağım Periyodu (SP) } & SKD x SP \\
\cline { 2 - 8 } Özellikler & SKÖ & SKS & P & Akşam & Sabah & P & P \\
\hline GSV & $2,66 \pm 0,08$ & $2,54 \pm 0,08$ & 0,0228 & $1,00 \pm 0,08$ & $1,60 \pm 0,08$ & $<0,0001$ & 0,0864 \\
YKM & $8,00 \pm 0,08$ & $7,85 \pm 0,08$ & $<0,0001$ & $7,99 \pm 0,09$ & $7,86 \pm 0,09$ & 0,0010 & 0,5534 \\
Yă $\breve{g}^{*}$ & $4,45 \pm 0,09$ & $4,46 \pm 0,08$ & 0,9189 & $4,51 \pm 0,10$ & $4,40 \pm 0,10$ & 0,3449 & 0,3449 \\
Protein & $2,92 \pm 0,03$ & $2,86 \pm 0,03$ & $<0,0001$ & $2,92 \pm 0,03$ & $2,86 \pm 0,03$ & 0,0030 & 0,1959 \\
Laktoz & $4,39 \pm 0,04$ & $4,32 \pm 0,04$ & $<0,0001$ & $4,39 \pm 0,04$ & $4,33 \pm 0,04$ & 0,0015 & 0,0601 \\
\hline
\end{tabular}

${ }^{*}$ Modelde kovaryant olarak yer alan süt miktarının etkisi istatistiksel olarak önemlidir (P $\left.\leq 0,05\right)$. GSV: Günlük süt verimi; YKM: Yağsız kuru madde; SKO: Sütten kesim öncesi; SKS: Sütten kesim sonrası.

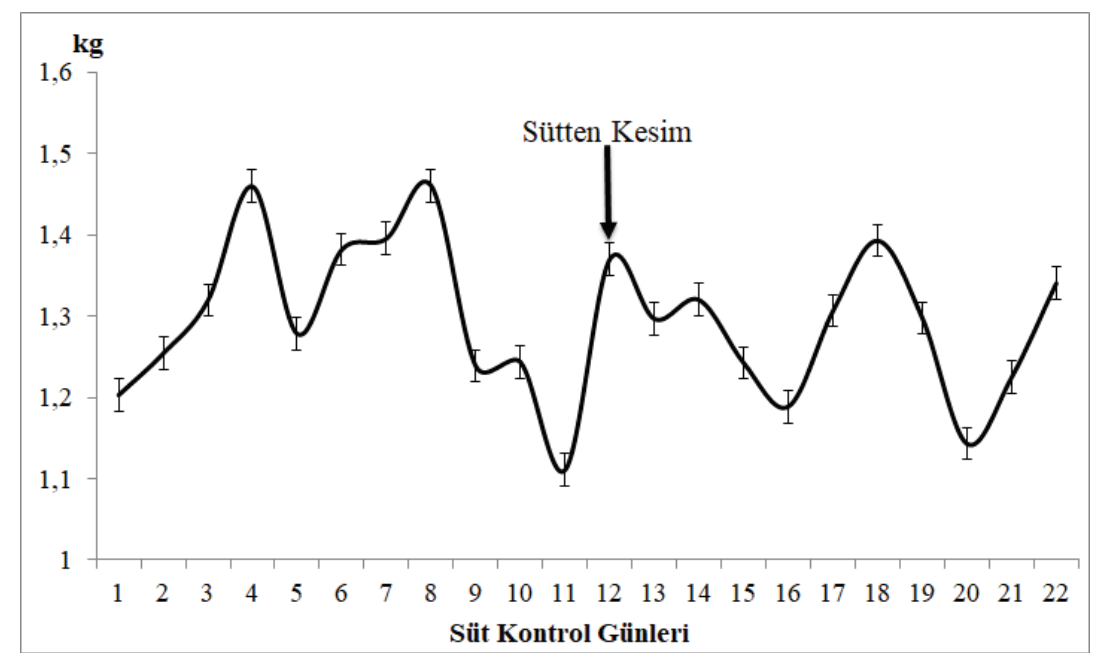

Şekil 2. Deneme boyunca Türk Saanen keçilerinin günlük süt verimi değişimi, kg 
Sütten kesim dönemleri ve sağım periyotlarına göre süt bileşenlerinde, yağsız kuru maddenin (YKM), protein ve laktozun istatistiksel olarak önemli ölçüde değiştiği tespit edilmiştir (Çizelge 2). Yağ dışındaki süt bileşenleri sütten kesim sonrasında öncesine göre önemli ölçüde düşüş göstermiştir $(\mathrm{P} \leq 0,05)$. Süt bileşenlerinden yalnızca laktoz sütten kesim sonrası birkaç gün sütten kesim noktasından daha yüksek iken, diğer tüm bileşenler sütten kesimden sonrasında düşük değerlerde seyretmiştir (Şekil 3). Süt miktarının artışı genellikle süt besin madde bileşenlerinde oransal bir düşüşe neden olduğu bilinse de (Tölü ve ark., 2010; Tölü ve ark., 2016), çalışmadaki bulgular tersini işaret etmektedir. Bu durum oğlağından ayrılan keçinin yaşadığı stresten kaynaklanabilir. Ancak bu stresin hangi fizyolojik yolla etkili olabileceği bu çalışma koşullarında elde edilen bulgularla açıklanamamaktadır. Stres koşullarında süt salınımında görev alan oksitosin hormonun sekteye uğrayabileceği bilinmektedir (Mckusick ve ark., 2001; Kulinova ve ark., 2012). Hamzaoui ve ark. (2013) sıcaklık stresi altındaki keçilerde süt miktarı, kuru madde, süt proteini ve laktoz içeriğinin düştüğünü ve süt yağ oranının ise etkilenmediğini bildirmişlerdir. Buna karşın Contreras-Jodar ve ark. (2018) yaptıkları çalışmada sıcaklık stresi altındaki süt keçilerinde süt protein ve laktoz oranı yanı sıra süt yăg oranının da düştüğünü rapor etmişlerdir. Murcia-Granada keçilerinde 7 haftalık yaşta oğlaklarından keçilerin doğumdan 48 saat sonra oğlaklarından ayrılan keçilere göre süt protein ve yağ içerikleri sütten kesim sonrası ve laktasyon boyunca düşük bir seyir izlemiş̧ir (Peris ve ark., 1997). Süt koyunlarında sütten kesimin annelerde etkisini belirlemek amacıyla yapılan çalışmada, sütten kesimden hemen sonrasında koyunlarda somatik hücre sayısının arttığı belirlenmiştir (Antonic ve ark., 2013). Sütten kesimin annelerde oluşturduğu stresi belirlemek amaciyla epinefrin hormon konsantrasyonun ölçüldüğü çalışmada, Angus x Hereford sığırlarında epinefrin hormonunun sütten kesimden sonra annelerde önemli ölçüde arttı̆̆ 1 belirlenmiştir (Lefcourt ve Elsasser, 1995). Orta laktasyon döneminde yer alan sığırlarda 5 gün boyunca damar yoluyla epinefrin hormonu verilerek süt verimi ve kompozisyonu izlenen çalışmada, epinefrin hormonun süt verimini geçici olarak düşürdüğü görülürken, süt bileşenlerinin oranlarını önemli ölçüde değiştirmediği belirlenmiştir (Naik ve ark., 2014). Angus x Hereford sığırlarında sütten kesim öncesi ve sonras1 5 günlük süreçteki davranış gözlemleri alınmış ve birden fazla doğum sırasına sahip olan annelerin ilkine doğum yapan annelerden önemli ölçüde daha fazla oranda yavrudan ayrılma stresi yaşadığı belirlenmiştir (Ungerfeld ve ark., 2011).
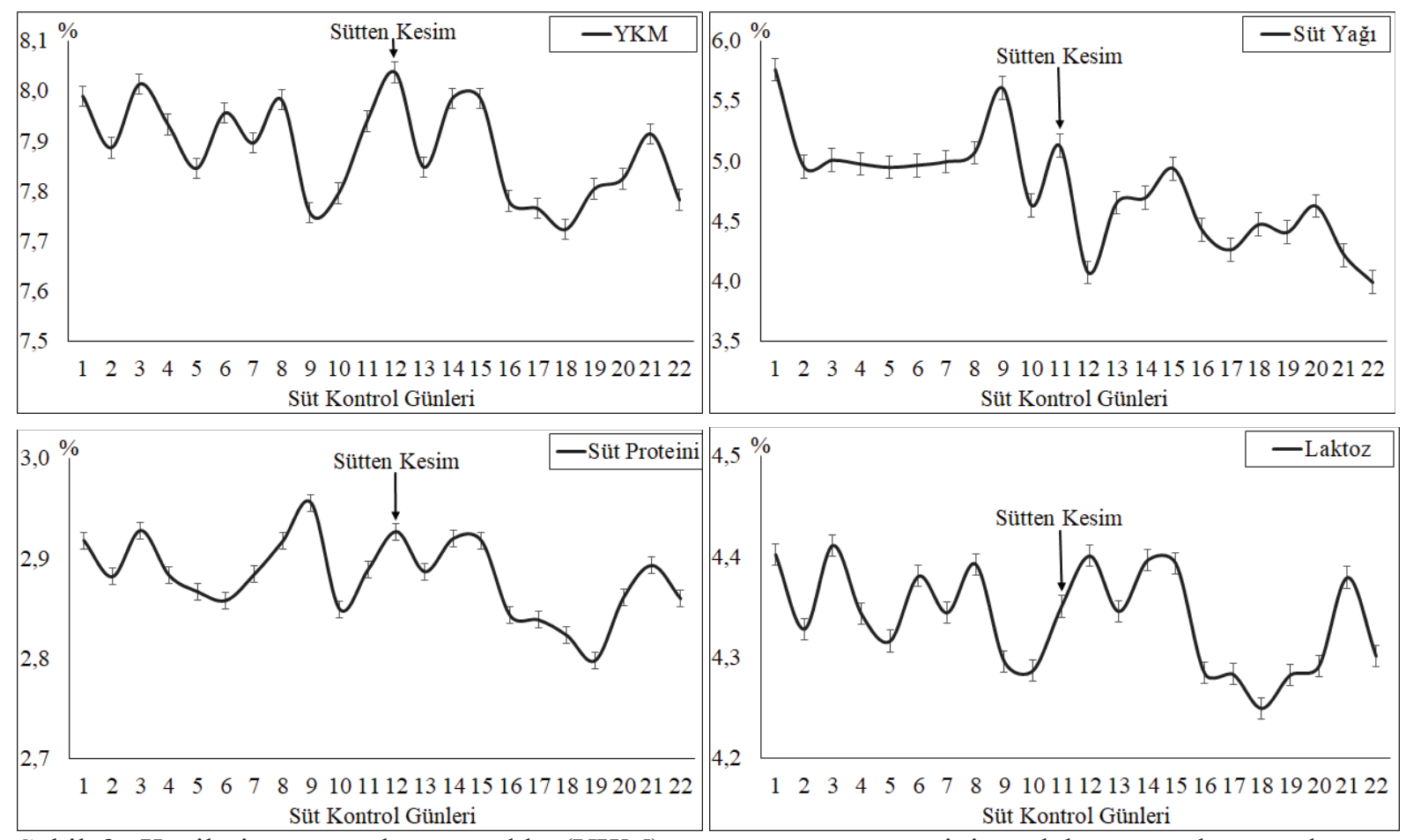

Şekil 3. Keçilerin yağsız kuru madde (YKM), süt yağı, süt proteini ve laktoz oranlarının deneme boyunca değişimi, \% 


\section{Sonuç ve Öneriler}

Türk Saanen keçilerinde sütten kesim sürecinin anne ve yavruda etkilerinin irdelendiği bu çalışmada, ortalama 60 günlük yaşta sütten kesilen erkek oğlaklarda canlı ağırlık değişiminde herhangi bir olumsuzluk görülmezken, dişi oğlakların sütten kesimden sonra canlı ağırlıklarının düştüğü ve 6 . günde dengelendiği görülmüştür. Süt tipi bir keçi ırkı olan Türk Saanen keçilerinde sütten kesimin, süt verimi ve kompozisyonunu önemli ölçüde olumsuz yönde etkilediği belirlenmiştir. Keçilerin süt miktarı, yağsız kuru madde, süt proteini ve laktoz oranları sütten kesim sonrasında önemli ölçüde düşmüştür. Keçilerin yavrularından ayrılmaları süt salgısını azalttığı gibi, süt besin madde kompozisyonlarının oranını da düşürmüştür. Türk Saanen keçilerinde sütten kesim periyodunun etkilerinin özellikle dişi oğlaklar ve anneler açısından daha fazla sayıda hayvan ve laktasyonun daha fazla sürecini kapsayacak şekilde araştırılmasına ihtiyaç olduğu düşünülmektedir.

\section{Teşekkür}

Yazarlar verilerin toplanması sırasında yardımlarından dolayı Ziraat Mühendisleri Kamile Gizem ARIKAN ve Serkan IRMAK'a teşekkür ederler.

\section{Kaynaklar}

Antonic, J., Jackuliakova, L., Uhrincat, M., Macuhova, L., Oravcova, M., Tancin, V., 2013. Changes in milk yield and composition after lamb weaning and start of machine milking in dairy ewes. Slovak J. Anim. Sci., 46,(3): 93-99.

Contreras-Jodar, A., Salama, A.A.K., Hamzoui, S., Vailati-Riboni, M., Caja, G., Loor, J.J., 2018. Effects of chronic heat stress on lactational performance and the transcriptomic profile of blood cells in lactating dairy goats. Journal of Dairy Research, 85: 423-430.

Deeming, L.E., Beausoleil, N.J., Stafford, K.J., Webster, J.R., Zobel, G., 2016. Brief communication: Variability in growth rates of goat kids on $16 \mathrm{New}$ Zealand dairy goat farms. Proceedings of the New Zealand Society of Animal Production, 76: 137-138.

Delgado-Pertínez, M., Guzmán-Guerrero, J.L., Mena, Y., Castel, J.M., González-Redondo, P., Caravaca, F.P., 2009. Influence of kid rearing systems on milk yield, kid growth and cost of Florida dairy goats. Small Rumin Res., 81: 105-111.

Hamzaoui, S., Salama, A.A.K., Albanell, E., Such, X., Caja, G., 2013. Physiological responses and lactational performances of late-lactation dairy goats under heat stress conditions. J Dairy Sci., 96: 6355-6365.

Keskin, M., Biçer, O., 2002. Effects of milk replacer on kid growth and farm profitability in the Shami goat. Turk J. Vet. Anim. Sci., 26: 1133-1136.

Kisac, P., Broucek, J., Uhrincat, M., Hanus, A., 2011. Effect of weaning calves from mother at different ages on their growth and milk yield of mothers. Czech J. Anim. Sci., 56(6): 261-268.

Kulinová, K., Mačuhová, L., Uhrinčat', M., Tančin, V., 2012. The effect of stressful treatment before and during milking on milkability of dairy ewes. Veterinarija ir zootechnika, 57: 39-43.

Lefcourt, A.M., Elsasser, T.H., 1995. Adrenal responses of Angus x Hereford cattle to the stress of weaning. J Anim Sci., 73(9):2669-2676.

Magistrelli, D., Aufy, A.A., Pinotti, L., Rosi, F., 2012. Analysis of weaning-induced stress in Saanen goat kids. J. Anim. Physiol. Anim. Nutr., 97(4): 732-739.

Magistrelli, D.; Pinotti, L.; Rapetti, L.; Rosi, F., 2011. Ghrelin, insulin and pancreatic activity in the periweaning period of goat kids. Journal of Animal Physiology and Animal Nutrition 95, 40-46.

Marnet, P.G., McKusick, B.C., 2001. Regulation of milk ejection and milkability in small ruminants. Livest. Prod. Sci., 70: 125-133.

McKusick, B.C., Thomas, D.L., Berger, Y.M., 2001. Effect of weaning system on commercial milk production and lamb growth of East Friesian dairy sheep. J. Dairy Sci., 84:1660-1668.

Morand-Fehr, P., 1981. Growth. In: Gall C., editor. Goat production. Academic Press; p. 253-284, London.

Naik, S.V., Singh, M., Sharma, H.D., 2014. Short term changes in plasma hormones, metabolites, milk yield and physiological responses in epinephrine administrated cows. J. Bio. Innov, 3(2): 63-72.

Pala, A., Savaş T., 2006. Relationship between daily, morning, evening and peak yield and persistency in Turkish Saanen goats. Animal Science Journal, 77: 532-537.

Pala, A., Savaş T., Uğur F., Daş G., 2005. Growth curves of Turkish Saanen kids grouped for weight and body mass index. Arch. Tierz., 48: 185-193.

Panzuti, C., Mandrile, G., Duvaux-Ponter, C., Dessauge, F., 2018. Early weaning and high feeding level in postweaning period did not impact milk production in Alpine dairy goats. J Dairy Res., 85: 277-280. 
Peris, S., Caja, G., Such, X., Casals, R., Ferret, A., Torre, C., 1997. Influence of kid rearing systems on milk composition and yield of Murciano-Granadina dairy goat. J Dairy Sci., 80: 3249-3255.

SAS, 1999. Institute Inc., SAS Online Doc®, Version 8, Cary, NC.

Savaş, T., 2007. Oğlak büyütme: Sorunlu noktalar üzerinde bir değerlendirme. Hayvansal Üretim, 48(1): 44-53.

Tancin, V., Bruckmaier, R.M., 2001. Factors affecting milk ejection and removal during milking and suckling of dairy cows. Vet. Med. Czech, 4: 108-118.

Tölü, C., Yurtman, İ.Y., Savaş, T., 2010. Gökçeada, Malta ve Türk Saanen keçi genotiplerinin süt verim özellikleri bakımından karşılaştırılması. Hayvansal Üretim, 51(1): 8-15.

Tölü, C., Savaş, T., 2012. Gökçeada, Malta ve Türk Saanen keçi genotiplerinin doğum ve oğlak büyümesi açısından karşılaştırılması. Hayvansal Üretim, 53: 17-25.

Tölü, C., Irmak, S., Açıkel, Ş., Akbağ, H., Savaş, T., 2016. Türk Saanen keçilerinde elle sağım ile makineli sağımın süt verimi, süt bileşenleri ve kalıntı süt bakımından karşılaştırılması. Tarım Bilimleri Dergisi, 22(3): 462-470.

Tölü, C., Arıkan, K.G., 2019. Süt keçilerinde Tart-Emzir-Tart (TET) ve Elle Sağım (ES) yöntemlerinin süt verimi ve bileşenleri ölçümlerinin karşılaştırılması. Hayvansal Üretim, 60(1): 1-7.

Uğur, F., Savaş, T., Dosay, M., Karabayır, A., Ataşoğlu, C., 2004. Growth and behavioral traits of Turkish Saanen kids weaned at 45 and 60 days. Small Rumin. Res., 52: 179-184.

Ungerfeld, R., Hötzel, M.J., Scarsi, A., Quintans, G., 2011. Behavioral and physiological changes in earlyweaned multiparous and primiparous beef cows. Animal, 5(8): 1270-1275.

Wollny, T., 2000. Mutterlose Aufzucht von Heidschnuckenlämmern unter besonderer Berücksichtigung der Anwendung eines Tränkeautomaten. Tierärztliche Hochschule Hannover, Dissertation, s. 181. 